
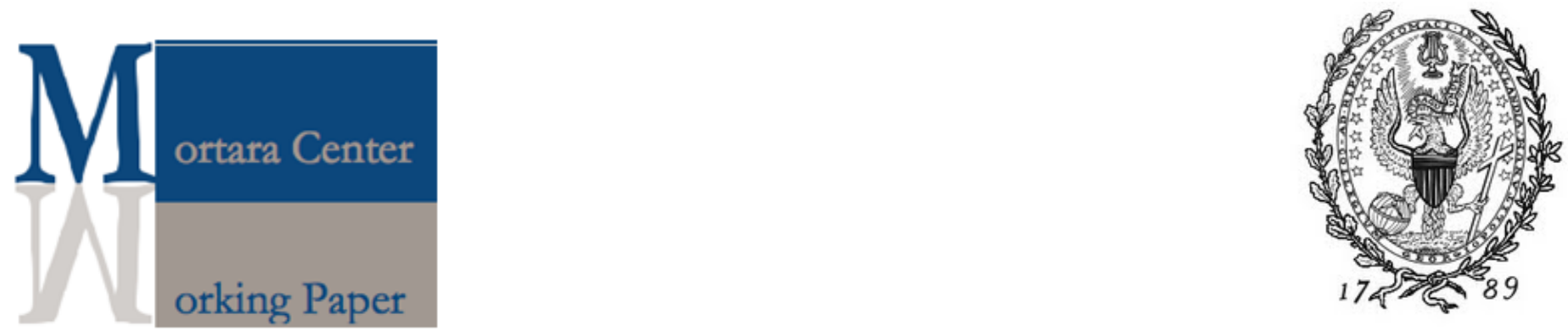

\title{
Buying Votes and International Organizations
}

\section{Axel Dreher}

Heidelberg University

James Raymond Vreeland

Georgetown University

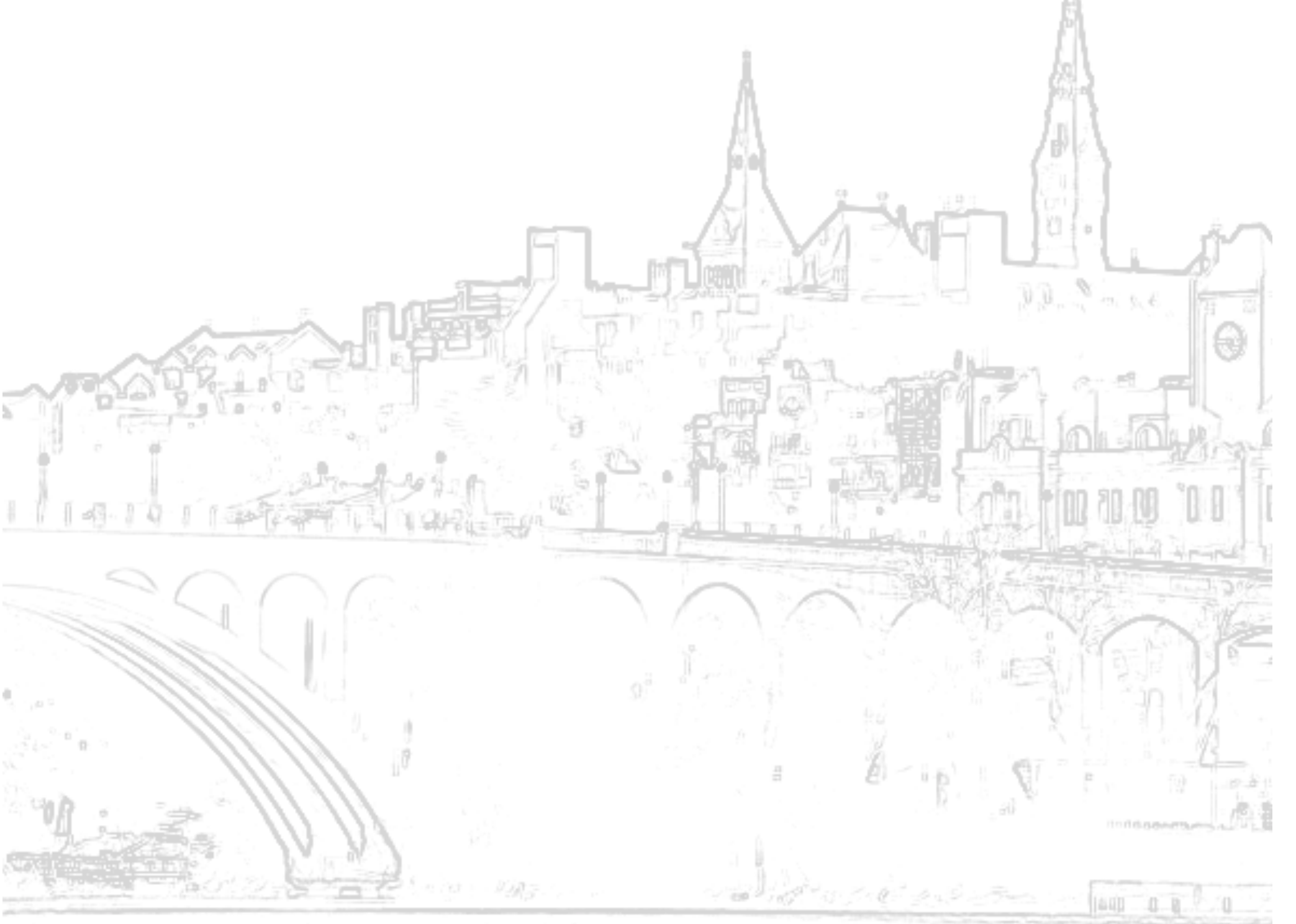

Mortara Working Paper 2011-9

May 2011

Mortara Center for International Studies Edmund A. Walsh School of Foreign Service Georgetown University 


\title{
Buying Votes and International Organizations
}

\author{
Axel Dreher ${ }^{\mathrm{a}}$ and James Raymond Vreeland ${ }^{\mathrm{b}}$
}

May 2011

\begin{abstract}
This study explores a basic idea in political economy: Trading money for political influence. Our focus is at the level of international institutions, where governments may exploit their influence in one organization to gain leverage over another. In particular, we consider the lending activities of the International Monetary Fund (IMF) and voting behavior at the United Nations Security Council (UNSC). Analyzing an original dataset on the successful and failed resolutions of the UNSC, we find evidence of vote-buying.
\end{abstract}

Keywords: IMF, UN Security Council, Voting, Aid

JEL-Codes: O19, O11, F35

${ }^{a}$ Heidelberg University, Alfred-Weber-Institut for Economics, Bergheimer Strasse 58, D-69115 Heidelberg, Germany, University of Goettingen, Germany, CESifo, Germany, IZA, Germany, and KOF Swiss Economic Institute, Switzerland, E-mail: mail[at]axel-dreher.de

${ }^{\mathrm{b}}$ Edmund A. Walsh School of Foreign Service and the Department of Government, Georgetown University, Washington, DC, E-mail: jrv24[at]georgetown.edu

Acknowledgements: We thank participants of the Political Economy of International Organizations IV conference (Zurich 2011), the European Public Choice Society Meeting (Rennes 2011), and, in particular, Lawrence Broz, Niklas Potrafke, and Dustin Tingley for helpful comments. 


\section{Introduction}

Recent events in Libya underscore a growing body of evidence suggesting that the approval of the United Nations Security Council lends legitimacy to the military actions of great powers. What is less understood - by the general public and scholars alike - is the process that produces the necessary votes to secure UNSC approval. This study explores a basic idea in political economy: Trading money for political influence. Our focus is at the level of international institutions, where governments may exploit their influence in one organization to gain leverage over another. In particular, we consider the lending activities of the International Monetary Fund (IMF) and voting behavior at the UNSC. Some developing countries that are elected to the UNSC may value IMF loans more than their votes on the Security Council. And the developed countries that virtually control the IMF may value Security Council votes more than the loans the IMF can provide. Trades are thus possible, and we employ an original dataset to explore the relationship between specific UNSC votes and IMF lending.

Previous research suggests that governments elected to the UNSC receive certain perks: More foreign aid from the United States, more programs from the World Bank, more money from the United Nations Development Program (UNDP), and more loans from the IMF with less stringent conditionality (Kuziemko and Werker 2006; Dreher, Sturm, and Vreeland 2009a, 2009b, 2010). If there really are foreign aid pay-offs for UNSC members, governments presumably trade the money for votes. Arguably, being a member but voting against the IMF's major shareholders should not benefit a country. Only if it votes in line with the United States, and other dominant members, would we expect membership to matter for IMF programs and money. This is what we investigate in this paper. We consider all available UNSC proposals those that have passed (resolutions) and those that have failed. To our knowledge, we are the first 
to analyze voting records at the UNSC in a panel data setting, and we present an original dataset collected from the United Nations (UN) Library in Geneva as well as from the UN web page.

Basically, our evidence suggests that the United States, the largest vote-holder at the IMF, rewards friends and punishes enemies. Elected members of the UNSC that vote with the United States are more likely to receive loans from the IMF, and the loans are larger. Conversely, elected UNSC members that vote against the United States receive loans that are fewer in number and smaller in size.

The paper proceeds as follows. After presenting brief backgrounds on the IMF and the UNSC, we present our argument in detail. Then we present the evidence. We conclude by speculating about the implications for global governance.

\section{The IMF and the UNSC}

One can think of the IMF as a credit union (Fischer 1999). Member-countries hold reserves on deposit at the institution, which the IMF can then loan to countries in need. The prospect of borrowing from the IMF during economic downturns may generate moral hazard, and so the IMF attaches policy conditions in return for continued disbursements of its loans. It is through these "IMF programs" that the organization most prominently interacts with governments mostly developing countries (from a broad historical perspective). Programs are developed by the IMF staff along with the recipient government, and the Executive Board of the IMF has the final say over the size of loans and the degree of policy conditionality that is attached.

Power on the IMF Executive Board is explicitly linked to economic size. Members have votes according to the financial contributions that they provide to the organization, and the financial contributions, in turn, are determined by economic weight. With nearly 17 percent of 
the total votes, the United States has veto power over certain decisions that require an 85 percent majority, such as the appointment of the IMF Managing Director. Beyond this formal power, the United States also has a degree of informal influence over the institution (Stone 2011). The IMF Executive Board typically operates according to a consensus rule, which gives the Management agenda-setting power. The Management, in turn, is subject to pressure from the United States, both because proposals are shaped to avoid US opposition and because - as the IMF headquarters are located in Washington - representatives of the US Federal Government are actively involved in important IMF meetings. A further channel of US influence is through the US Congress, which must periodically approve increases in US contributions to the IMF (Broz and Hawes 2006; Broz 2008, 2011). As the United States is the largest contributor and influences other contributors on whether to approve increases, the IMF Management and Staff pay due attention to the preferences of US policy-makers.

There is a good deal of evidence that the United States uses its influence at the IMF to favor the governments of developing countries it considers strategically important. Anecdotal evidence abounds (e.g., Andersen, Hansen and Markussen 2006; McKeown 2009). The first scholar to provide systematic evidence is Thacker (1999), who shows that IMF programs are more likely to go to governments that move towards the United States in terms of their voting at the United Nations General Assembly (UNGA). Dreher and Sturm (2010) show that the correlation holds across the G7 countries. The UNGA findings are further corroborated by Barro and Lee (2005) and Dreher and Jensen (2007). Research also shows that developing countries that are heavily indebted to US banks receive larger loans (Oatley and Yackee 2004; Broz and Hawes 2006). Stone $(2002,2004)$ shows that governments favored by the United States in terms of bilateral aid, which is well-known to be influenced by international politics, receive lighter 
punishments for noncompliance with IMF conditionality. He concludes, "Although the United States holds a minority of votes, it does indeed call the shots at the IMF, as critics allege" (2002: 62). Woods (2003) documents that the United States virtually controls major decisions at the IMF; Fratianni and Pattison (2003) summarize evidence showing that the G7 are in control of the IMF on the most important issues and that staff autonomy is restricted to areas that are of marginal interest to its shareholders. Copelovitch (2010) shows that political influence is strongest when the major shareholders agree on the importance of a country. Faini and Grilli (2004) report that IMF lending is influenced by the United States and the European Union. In the words of Rieffel (2003: 28-29), "The IMF is an instrument of the G-7 countries. There is no example that comes easily to mind of a position taken by the IMF on any systematic issue without the tacit, if not explicit, support of the United States and the other G-7 countries."

Of central importance to this study, Dreher et al. (2009a, 2010) show that elected members of the UNSC are more likely to participate in IMF programs and the conditions attached are fewer in number and narrower in scope than for other countries. They do not find any effect on loan size - a matter to which we return below. Still, we take the other findings as evidence of IMF favoritism for UNSC members. As the argument goes, the major shareholders of the IMF - the United States, Japan, Germany, France, and the United Kingdom - desire influence on the UNSC. The governments of some developing countries may care more about the foreign exchange that the IMF can provide than they care about the global security issues considered important by the IMF's major shareholders. Trades of UNSC votes for IMF loans are thus possible. 
This raises some questions: why do the major shareholders care about UNSC votes? Why should they use the IMF to obtain leverage over UNSC members? And are the IMF loans in fact correlated with voting behavior at the UNSC?

With respect to the first question, the UNSC is the primary organ of the United Nations with responsibility for the maintenance of international peace and security. The Security Council has the power to make binding resolutions and may adopt legally binding measures in order to maintain or restore international peace - including the investigation of international disputes, the imposition of economic sanctions, and the use of armed forces in military actions.

Historically, when the United States acts in concert with the UNSC, it bears a smaller share of the burden of international campaigns (Sandler and Hartley 1999). So, it stands to reason that the United States should care about UNSC resolutions. Yet, the elected members of the UNSC have a limited impact on passing them. Veto power on the Security Council belongs to each of the five permanent members (the victors of World War II: China, France, Russia, the United Kingdom, and the United States). The ten elected members, which represent various regions of the world, are rarely pivotal (O'Neill 1996). Still, nine total votes are required for a resolution to pass, and since permanent members frequently abstain, upwards of four out of the ten elected members must vote in favor.

A more likely reason to care about the votes of elected UNSC members, beyond their formal voting power, is legitimacy (Voeten 2005; Hurd 2007; Caron 1993; Claude 1966). As Hurd (2007) explains, the elected members serve the purpose of giving voice to the "rest of the world" on the Security Council. And the legitimizing effect of the Security Council may extend beyond the international level and into domestic politics. For example, Chapman and Reiter (2004) find that US Presidents enjoy higher levels of public support for actions endorsed by the 
UNSC, an effect not found for any other international organization they test. ${ }^{1}$ In the absence of UNSC legitimacy, domestic public support might be more difficult to achieve and the US Congress might be recalcitrant (Voeten 2001; Hurd 2007; Hurd and Cronin 2008). Voeten (2001) provides examples. He cites the memoirs of James Baker (1995: 278), emphasizing domestic support to be the main reason for the US government to seek a multilateral solution to the Gulf War. He also cites Malone (1998: ix), arguing that it was easier for the Clinton administration to secure the support of the UNSC as compared to that of the US Congress. ${ }^{2}$ There is thus a premium for getting (nearly) unanimous votes (see, e.g., Doyle 2001: 223), and every single vote matters.

Although no one has systematically studied UNSC voting behavior to see if it is influenced by the IMF, there is a growing body of circumstantial evidence that the United States regularly engages in vote-buying at the Security Council. Eldar (2008: 17-18) provides examples. For one, the United States promised to support a World Bank loan for China in return for support on the Security Council for the first Gulf War in 1991. As another example, the United States again helped China obtain World Bank loans (and provided security guarantees regarding Taiwan) in return for allowing a UNSC resolution to restore democracy in Haiti in 1994. More generally, Eldar (2008: 17) argues that in order to get UNSC support for the Gulf War, the United States made "a promise of financial help to Columbia, Côte d'Ivoire, Ethiopia and Zaire; a promise to the USSR to keep Estonia, Latvia and Lithuania out of the November 1990 Paris Summit conference and to persuade Kuwait and Saudi Arabia to provide it with hard

\footnotetext{
${ }^{1}$ For more a broader analysis of this question, see Chapman (2011).

2 The legitimacy may derive from the idea that the UNSC members have been elected to represent their respective regions and also from the idea that UNSC votes represent informed decisions. Members of the UNSC have access to sensitive documents and private discussions regarding the importance of taking international action. For more on these informational theories, see Fang (2008), Chapman (2007), and Thompson (2006a).
} 
currency..." He further argues that before the second Gulf war, the United States again attempted to buy votes of temporary UNSC members.

As an older example, consider the experience of Tanzania. ${ }^{3}$ Following independence in 1961, the government did not enter into an IMF arrangement for a decade and a half. Then Tanzania ran for election to the UNSC in the fall of 1974. That year it received 6.3 million SDR from the Oil Fund Facility, a special facility that involved no conditionality (IMF Survey 1974: 86). The government received a second Oil Facility loan for 3.15 million SDR in 1975 (IMF Survey 1975: 77). Tanzania finally entered into a one year stand-by arrangement for 10.5 million SDR on 21 August 1975 (IMF Survey 1975: 254). Stein (1992) reports that the policy conditions associated with this arrangement were weak. Tanzanian President Julius Nyerere used his high international profile to negotiate for soft conditionality.

Beyond these anecdotes, there is a growing body of evidence of systematic favoritism, as documented above: More bilateral aid from the United States, a small boost in funding from the United Nations Development Program (particularly through UNICEF, where the United States provides the most contributions), more projects from the World Bank, and more loans from the IMF with less stringent conditionality. ${ }^{4}$

Even supposing that the United States government cares about votes on the UNSC, why should it go through the IMF to exert influence? Dreher et al. (2009b) present three arguments relating to political cover, leverage, and cost. Regarding political cover, using the IMF obfuscates the process of vote-buying, laundering the dirty work of the governments (see Vaubel 1986, 1996, 2006; Abbott and Snidal 1998). In terms of leverage, recall that the IMF does not

\footnotetext{
${ }^{3}$ See Vreeland (2003: chapter 2).

${ }^{4}$ Lim and Vreeland (2011) show that UNSC members also receive a greater share of Asian Development Bank loans, though they argue that here the influence is more Japanese than American.
} 
provide the entire loan upfront, and continued disbursements are conditioned - in principle - on economic policy changes. The IMF Executive Board, however, has the final word on all disbursements and has discretion in deeming countries compliant (Stone 2002, 2004; Harrigan et al. 2006). While the Board certainly must contend with the Fund's internal rules, and all studies of the determinants of IMF lending show that economic variables guide IMF lending, a growing body of literature indicates that international politics matter as well. ${ }^{5}$ Finally, and perhaps most obviously, when they provide foreign aid through the IMF, the major shareholders pay a fraction of the cost rather than the total (Eldar 2008).

Theory and circumstantial evidence notwithstanding, the empirical question of whether IMF loans are correlated with actual voting behavior on the UNSC still remains. It is to this question that we now turn.

\section{Data, analysis, results}

We consider two dependent variables: (1) a dichotomous indicator of participation in IMF programs and (2) the size of IMF loans. ${ }^{6}$ In our largest sample, the data cover 1951 to 2004. During this time period, 122 out of a total of 159 countries participated in IMF programs. There are a total of 1,656 country-year observations under IMF programs out of a possible 4,694 total country-year observations in this dataset. For countries that participated, the median IMF loan committed was 62 million SDRs. Note that the IMF provides overall commitments for the whole

\footnotetext{
${ }^{5}$ See Sturm, Berger and de Haan (2005), Steinwand and Stone (2008) and Moser and Sturm (2011) for reviews. For in depth consideration of international political factors, see Thacker (1999), Stone (2002, 2004), Dreher and Jensen (2007), Oatley and Yackee (2004), Barro and Lee (2005).

${ }^{6}$ Data on IMF participation come from the update to Vreeland (2007). Data on loan size and on participation in concessional lending come from an update of Dreher (2006) and the IMF's International Financial Statistics.
} 
period of a program only, rather than breaking them down to individual years. We therefore divide commitments by program duration, assuming equal phasing over the program period.

Using this dataset, we test our primary hypotheses: Elected UNSC members that vote with the United States are more likely to participate in IMF programs, and they receive larger IMF loans; elected UNSC members that vote against the United States are less likely to participate in IMF programs, and they receive smaller IMF loans.

To this end, we create an indicator variable coded 1 during years that a country is a temporary member of the UNSC. We also code a separate variable for the percentage of UNSC proposals where the country votes with the United States, and another variable for the percentage of UNSC proposals where the country votes against the United States. The data for these variables have been collected from various sources. Voting behavior on successful resolutions is available from the official UN website (http://unbisnet.un.org/). We added information on vetoed resolutions from the official United Nations veto list (UN document A/58/47) and archival research in the UN Library in Geneva. Most difficult to obtain are data on failed majorities. We include voting behavior on these failed majorities obtained from our research in the UN library (these data are, however, incomplete). Overall, we obtained data for 1,489 resolutions, 165 vetos, and 18 failed majorities over the 1951-2004 period. This is the most extensive dataset on UNSC voting of which we are aware.

In constructing an index of voting alignment with the United States, we follow the literature on voting in the UNGA, which has proposed alternative approaches. Thacker (1999), for example, codes votes in agreement with the United States as 1, votes in disagreement as 0 , and abstentions or absences as 0.5. Wittkopf (1973), Sexton and Decker (1992) and Barro and Lee (2005) employ the fraction of times a country votes the same as the country of interest 
(either both voting yes, both voting no, both abstaining, or both being absent); Kegley and Hook (1991) discard abstentions or absences and consider how often countries are in agreement when they vote yes or no. All approaches then tally the annual scores according to their respective coding rules and divide by the total number of votes in each year. Below, we employ the method proposed by Kegley and Hook, discarding abstentions and absences. Our main results are also robust to using the method proposed by Wittkopf, where abstentions and absences count. Note that for observations of countries not on the UNSC, these variables are coded 0 .

The indicator for temporary UNSC membership is coded 1 for 458 out of 7,237 observations. This makes sense - in any given year, there are ten countries serving as elected UNSC members. For countries on the UNSC, the mean of the "Voting with the USA" variable is 0.91 (and 0.06 for all observations); the median is 0.96 . The mean of the "Voting against the USA" variable is 0.07 (and 0.004 for all observations). So, countries typically vote together on UNSC resolutions. There is, however, some variance, and we seek to understand if that variance can explain IMF lending.

We proceed as follows: First, we present descriptive data, which provide preliminary confirmations of our hypotheses. Then we turn to more rigorous regression analysis.

\subsection{Descriptive evidence}

Consider figures 1 through 4 . In each, the x-axis presents voting behavior at the UNSC, and the $\mathrm{y}$-axis presents the percentage of country observations participating in IMF programs, or, alternatively, the (logged) size of the IMF loan (we report commitments as opposed to disbursements). In these figures, we consider only observations of UNSC members (below, we also compare them to countries not on the UNSC). 
Figure 1 shows no clear pattern. On the one hand, the data seem to fit our hypothesis when the United States votes "yes": Participation is highest for countries voting "yes" and lowest for countries voting "no." But when the United States votes "no," participation is highest for countries that disagree, voting "yes," and lowest for countries that agree, voting "no." The data on abstentions are inconclusive. So, independent of the voting behavior of the United States, countries voting "yes" on the UNSC are most likely to be under an IMF program. Still, the share of countries under an IMF program is higher for countries voting "no" when the United States also votes "no" as compared to when countries vote "no" and the United States votes "yes." This evidence supports the view that the United States rewards friends and punishes enemies at least when countries are voting "no."

Figure 2 focuses on concessional programs only. "Concessional" IMF programs are those with concessional interest rates - they go towards the poorer borrowers from the IMF and typically involve conditionality geared towards long-run economic growth as opposed to shortrun adjustment. This figure shows a clearer picture. ${ }^{7}$ Countries voting in line with the United States on either "no" votes or "yes" votes are most likely to be under an IMF program. This descriptive evidence is thus favorable for our hypothesis.

Figures 3 and 4 focus on the size of loan commitments, respectively, for all programs combined and for concessional lending only. The pattern that emerges from both of these pictures supports our hypothesis. The highest commitments go to countries voting "yes" when the United States votes "yes" and "no" when the United States votes "no"; the lowest commitments go to countries voting "no" when the United States votes "yes" and "yes" when the

\footnotetext{
${ }^{7}$ Note that our indicator variable is coded one if a concessional program is in effect for at least five months during a particular country-year (as taken from Dreher 2006).
} 
United States votes "no"; abstentions are in the middle. Countries voting with the United States receive higher commitments.

We draw one key conclusion from the descriptive data: While previous research shows that countries serving on the UNSC are more likely to receive loans from the IMF, this may not hold for all members. It depends on whether the country votes in line with the IMF's largest shareholder, the United States. Now, we do not know from the comparisons presented in these figures what the voting patterns would look like in the absence of IMF lending. It is possible that the voting pattern would resemble the US pattern even less than we actually observe without the influence of IMF lending. Or, perhaps, there is no IMF-effect at all. Of course, there are many reasons that countries enter into IMF programs and receive loans. How much IMF lending can be attributed to UNSC voting behavior? And does voting behavior on the UNSC have a statistically significant impact after accounting for economic, political, historical, and geographical differences? To address these questions, we turn to more rigorous analysis.

\subsection{Regression analysis}

For the analysis of IMF participation, we employ a dichotomous indicator in a logit model conditioned on countries to control for fixed effects. We draw on Dreher et al. (2009a), who follow Cameron et al. (2006) and Thompson (2006b), clustering the covariance matrix in the country and year dimensions simultaneously. ${ }^{8}$ This provides cluster-robust inference allowing for both serial and spatial correlation.

${ }^{8}$ As Dreher et al. (2009) explain, Cameron et al. (2006) and Thompson (2006b) show that a
multi-way clustered covariance matrix can be constructed by adding the two non-nested
clustered covariance matrices together, then subtracting the relevant White matrix to avoid
double counting. This approach also works for nonlinear estimators such as logit and probit. The 
For the size of IMF loan commitments, we analyze the log of commitments in millions of current SDRs using a linear model with country and year fixed-effects and standard errors clustered at the country-level. ${ }^{9}$

For both dependent variables, we begin with the same specification used in Dreher et al. (2009a), including past participation in IMF programs, (log) per capita GDP, investment (in percent of GDP), debt service (in percent of GDP), (log) checks and balances, and the government's budget surplus (in percent of GDP). ${ }^{10}$

Columns 1 through 3 of Table 1 present the main results for the dichotomous indicator of IMF program participation. Throughout, the control variables have the expected signs, in line with previous studies, and are all significant at the five percent level (or stronger). We focus on the independent variables of principle interest for this study: UNSC membership, Voting with the USA, and Voting against the USA.

Column 1 reproduces Dreher et al. (2009a), showing that countries on the UNSC are more likely to participate in IMF programs than other countries, a finding that is statistically significant at the one percent level. When we introduce Voting with the USA, in column 2, things change. Recall that Voting with the USA takes on a value of zero when UNSC is coded 0 , and is coded as the percentage of votes in common with the United States when UNSC is coded 1. So, one can think of Voting with the USA as an interaction with UNSC. The coefficient for

variance estimator extends the standard cluster-robust variance estimator or sandwich estimator for one-way clustering and relies on similar, relatively-weak distributional assumptions.

${ }^{9}$ We add "one" to account for zero values when taking the log. Note that the estimates would be identical if we employed loans in real terms, due to the inclusion of year fixed effects. The approach we employ is standard in the aid allocation literature (e.g., Kilby 2011).

10 The specification has been derived with a general-to-specific procedure to a specification including the most robust control variables as identified by Sturm, Berger and de Haan (2005). See Sturm, Berger and de Haan (2005) and Moser and Sturm (2011) for a detailed description of the associated hypotheses. 
UNSC membership is not significant, while the positive coefficient for Voting with the USA is significant at the ten percent level. The insignificance of the former is due to multicollinearity (rho=0.98); the two variables are jointly significant at the one percent level. The negative coefficient for UNSC and the positive coefficient for Voting with the USA imply that if a country is on the UNSC and fails to vote with the United States, it is not more likely to participate in an IMF program; while if a country is on the UNSC and does vote with the United States, it is more likely to participate in an IMF program. Calculating the substantive effect (at the mean of the independent variables assuming the fixed effects to be zero, and holding UNSC membership at one), we find that a one percent increase in Voting with the USA from the value of 0.9 increases the probability of being under an IMF program by 1.64 percent. Note that even in the presence of the high correlation between UNSC membership and Voting with the USA these estimates are unbiased and consistent. Specification tests show that the significance of the coefficient depends on two observations: The votes of Yemen in 1990 and 1991. There is the famous story of the United States cutting aid to Yemen in 1990/91 when the government of Yemen voted against the US-supported resolution for Desert Storm. Yemen did also not receive an IMF loan until 1996 (see Dreher et al. 2009a). ${ }^{11}$ This episode seems to drive these particular findings.

Column 3 shows symmetric results when we control for Voting against the USA. The positive coefficient for temporary UNSC membership indicates that UNSC members that avoid voting against the United States are more likely to participate in IMF programs, while the coefficient for Voting against the USA indicates that UNSC members voting against the United States are less likely to participate in IMF programs - both findings are statistically significant at

\footnotetext{
${ }^{11}$ Secretary of State Baker passed a note to the Yemini ambassador after the vote had been taken that read, "That is the most expensive vote you have ever cast" (Bandow 1992).
} 
the five percent level (or stronger). The corresponding elasticity implies that countries voting against the United States, say, 10.1 percent of the time instead of just 10 percent of the time are 0.3 percent less likely to be under an IMF program. Note that the correlation between UNSC membership and Voting against the United States is only 0.66 . The lower correlation compared to those between membership and voting with the United States allows less room for outlying observations to dominate the results.

Columns 4 through 8 of Table 1 present the results for the size of IMF loans. (Again, the control variables have the expected signs, though they are not all statistically significant.) Column 4 reproduces Dreher et al. (2009a), showing that countries on the UNSC do not receive larger loans. When we introduce Voting with the USA, in column 5, things change. The coefficients of -1.71 for temporary UNSC membership and 2.09 for Voting with the USA indicate that if a country is on the UNSC and fails to vote with the United States, it receives a smaller loan. And if a country is on the UNSC and does vote with the United States, it receives a larger loan. More precisely, for an increase in voting with the United States of one percent, the country receives 14 percent more in IMF loans. ${ }^{12}$ The results are stronger in column 7 , where we drop the control variables that are not statistically significant at conventional levels. Again, however, the results are driven by Yemen and can thus not be generalized.

Columns 6 and 8 perform similar analyses switching Voting with the USA for Voting against the USA, with similar but stronger results. In column 8, the net effect of voting against the United States by one percent is to decrease IMF loans by -2.3 percent, while the UNSC variables are not significant at conventional levels in column 6 . Figure 5 shows that this result is not driven by outliers.

${ }^{12}$ Using Stata, we report the elasticity calculated with $\mathrm{mfx}$, dyex. The elasticities are not presented in the tables, but are calculated from the results presented therein. 
Note that the findings presented here indicate that voting behavior at the IMF influences all types of conditional lending from the IMF, concessional and non-concessional alike. Given what we observe in the figures above, we also repeat our analysis focusing on concessional IMF programs only. The qualitative results hold but are actually weaker than the results presented above. These results are not reported but are available as part of the replication materials.

Table 2 replicates the analysis but includes a country's voting similarity with Russia (or the Soviet Union, depending on the historical period). Voting behavior in the UNSC among the other permanent members is too high to include them in the same regression. While correlation between voting with the United States and Voting with Russia is also high (rho=0.95), correlation of Voting against the USA and Voting against Russia is notably lower (rho $=0.03$ ). While insignificant results on the former could thus result from multicollinearity, there should be no problem identifying separate effects of voting against Russia and, respectively, against the United States, if any. The results show that voting with or against Russia does not have a statistically significant impact while the statistical significance of the results for voting with/against the United States remains. Overall, it seems that the Western shareholders specifically the United States - rather than Russia exert influence in the Fund to channel additional programs to countries voting with them in the UNSC. This interpretation makes sense - the Soviet Union was never a member of the IMF, and the vote share of Russia at the IMF Executive Board is low compared to those of the United States and its allies. These results thus lend confidence to our overall interpretation of the above results that the effect of voting against the United States influences IMF lending behavior.

One question we left open is about the direction of causality. As we currently model it, voting on the UNSC causes IMF loans. But it is also plausible that IMF loans cause UNSC 
voting. A formal test for causality using instrumental variables is beyond the scope of this paper. Here, we are mainly interested in whether IMF lending is influenced by its major shareholders for geo-political considerations. Whether IMF loans are used to change the voting behavior of countries in the UNSC or countries are rewarded for their voting is of secondary importance. Also, we are not aware of an instrument that could be used to disentangle these two effects. Even if we find (by means of Granger causality tests, e.g.) that IMF loans precede a change in voting behavior we could not know whether the loan is paid as a reward or rather as a bribe. Even if the loan precedes the vote, it could well be paid in anticipation of a positive vote rather than a bribe. We thus leave this question for future research. Note however that some anecdotes indicate that the direction of causality is as we have it: Voting causes loans (as in the example of Yemen mentioned above).

Finally, we turn to whether the United States uses IMF money to reward its friends or rather bribes its opponents. Following previous work (like Thacker 1999), we use a country's position in the UNGA to proxy for political proximity. ${ }^{13}$ In column 1 of Table 3 we add the share of votes a country votes the same as the United States in the UNGA to the conditional fixed effects Logit model. We lag the variable by one year as contemporaneous voting is likely to be affected by the same dynamics also affecting the size of the loan. ${ }^{14}$ The results show that voting with the United States in the previous year does not affect the probability of receiving an IMF program at conventional levels of significance. The results for UNSC membership and voting against the United States on the UNSC remain.

\footnotetext{
${ }^{13}$ We measure voting with the United States in the UNGA analogously to how we measure voting with the United States in the UNSC.

${ }^{14}$ For example, a country receiving an IMF loan in reward for its voting compliance in the UNSC will likely also change its voting in the UNGA.
} 
Column 2 adds the interaction of voting with the United States in the UNGA (lagged) and voting against the United States in the UNSC. Interpreting the interaction effect in nonlinear models such as logit is not straightforward (Ai and Norton 2003, Greene 2010). ${ }^{15}$ Figure 6 thus illustrates the quantitative effect of voting against the United States on the UNSC and its significance. We graph the marginal effect of a change in voting on the probability to be under an IMF arrangement for different values of voting in the UNGA, holding the additional continuous explanatory variables to their means, setting the UNSC dummy equal to one and the dummy for past arrangements to zero, and assuming the country fixed effects to be zero. The results show that the marginal effect decreases with voting inline with the USA in the UNGA but is not significant at the ten percent level at most values of UNGA voting. The exceptions are the marginal effects in the range of $0.3-0.5$, with negative coefficients. Taking this at face value, it implies that neither friends nor enemies of the United States are punished for voting against the United States in the UNSC. Rather, it is the countries in the middle - the "swing voters" whom the United States targets. ${ }^{16}$ Quantitatively, an increase in voting against the United States in the UNSC from zero to one reduces the probability to be under an IMF program by 0.06 percentage points.

Columns 3 and 4 replicate the results focusing on loan size rather than programs. As column 3 shows, countries voting in line with the USA in the previous year receive larger IMF loans, at the five percent level. The coefficient implies that an increase in voting in line with the United States in the UNGA by 0.1 will increase IMF loans by 86 percent $(=0.1 *(\exp (2.155)-1)$.

\footnotetext{
${ }^{15}$ As Ai and Norton (2003: 123) point out, "the magnitude of the interaction effect in nonlinear models does not equal the marginal effect of the interaction term." It can even be of opposite sign. Moreover, a simple t-test on the coefficient of the interaction term is not appropriate to test for the significance of the interaction.

${ }^{16}$ See Dixit and Londregan (1996) on the logic of targeting swing voters.
} 
Column 4 adds the interaction term, which has a negative coefficient, significant at the five percent level. Figure 7 depicts the elasticity for varying ranges of UNGA voting. The results imply that enemies of the United States do not get punished by the IMF when they vote against the United States on the UNSC but friends do.

Taken together, the results tell an interesting story about the determinants of who receives IMF loans and how big the loans are. Swing voters are targeted for IMF participation: when countries that vote with the United States part of the time at the UNGA choose to vote against the United States at the UNSC, they are less likely to receive an IMF loan. Friends of the United States are targeted with respect to loan size: When countries that vote with the United States at the UNGA choose to vote against the United States at the UNSC, they receive smaller IMF loans. The United States does not appear to exert political capital to influence enemies: Cuntries that do not vote with the United States at the UNGA are note targeted for votes at the UNSC.

\section{Conclusion}

The aftermath of the Global Financial Crisis led to the reform of IMF governance. Changes were made in the name of legitimacy: If the IMF is to remain relevant, its governance structure must represent realities about the relative economic strength of its members. So, in 2012, emerging market countries will see their vote shares (and contributions) increase, while the relative power of Western countries will be reduced. Notably, China will move from the sixth largest voteholder to the third. But the most powerful member will remain the United States, retaining not only its top position, but also its veto power over key decisions at the IMF.

One reason these governance reforms are important - and proved controversial - is that the most powerful members of the IMF do employ the institution to pursue their self-interest. 
Ironically, the powerful members of the IMF have, apparently, used their influence to buy legitimacy from another international organization. Power at the IMF translates into additional power at the UNSC.

Recent research has shown that UNSC membership is associated with a greater probability of participating in IMF programs and with less conditionality in terms of the number of specific policy conditions. UNSC members also get more World Bank loans, US bilateral aid, and more money from the UNDP. Our study is the first to consider actual voting behavior, and we show that it matters.

Voting with the United States is rewarded and voting against the United States is punished. The substantive effect of voting with the United States is statistically significant, but small (and driven by two outlying observations) - that of voting against the United States is also statistically significant and larger - by an order of magnitude (and not driven by outliers). The analysis of our original dataset leads to a straightforward conclusion: The United States uses its influence at the IMF to buy votes on the UN Security Council. Governments serving on the Security Council who publicly disagree with the United States on matters of international security are less likely to receive IMF loans, and if they do receive them, the loans are significantly smaller.

We are left with an intriguing conclusion. The United States may seek to legitimate its foreign policy objectives with approval from the UNSC, but that approval may, in part, be bought by trading votes for loans, and activity that is inconsistent with the stated objectives of the IMF, and thus may be viewed as less than legitimate. To the extent that a trade like this is possible, we believe that it can only be so because international organizations are not completely 
transparent and are not well-understood by the general public. International organizations can thus be used to do the "dirty work" of governments (Vaubel 1986, Abbot and Snidal 1998). 


\section{References}

Abbott, Kenneth and Duncan Snidal. 1998. Why States Act Through Formal International Organizations. Journal of Conflict Resolution 42 (1):3-32.

Ai, Chunrong and Edward C. Norton, 2003. Interaction Terms in Logit and Probit Models, Economics Letters 80, 1: 123-129.

Andersen, Thomas B., Hansen, Henrik and Markussen, Thomas. 2006. US politics and World Bank IDA-lending, Journal of Development Studies 42, 5: 772-794.

Baker, JA III, 1995. The Politics of Diplomacy: Revolution, War and Peace: 1989-1992. Putnam's: New York.

Bandow, Doug, 1992, Avoiding War, Foreign Policy Magazine 89 (Winter): 156-174.Barro, Robert J. and Jong-Wha Lee, 2005, IMF-Programs: Who Is Chosen and What are the Effects? Journal of Monetary Economics 52: 1245-1269.

Broz, J. Lawrence, 2008, Congressional Voting on Funding the International Financial Institutions, Review of International Organizations 3, 4: 351-374.

Broz, J. Lawrence, 2011, The United States Congress and IMF Financing, 1945-2009, Review of International Organizations 6, 2-3, forthcoming.

Broz, J. Lawrence and Michael B. Hawes, 2006, US Domestic Politics and International Monetary Fund Policy, in: Darren Hawkins, David A. Lake, Daniel Nielson, and Michael J. Tierney (eds.), Delegation and Agency in International Organizations, Cambridge University Press: 77-106.

Cameron, A. Colin, Gelbach Jonah B., Miller Douglas L., 2006. Robust inference with multiway clustering. NBER Technical Working Paper No. 327, September. 
Caron, David D., 1993, The Legitimacy of the Collective Authority of the Security Council, American Journal of International Law 87, 4:552-88.

Chapman, Terrence L. and Dan Reiter, 2004, The United Nations Security Council and the Rally 'Round the Flag Effect, Journal of Conflict Resolution 48, 6: 886-909.

Chapman, Terrence L., 2007, International Security Institutions, Domestic Politics, and Institutional Legitimacy, Journal of Conflict Resolution 51, 1: 134-166.

Chapman, Terrence L. 2011. Securing Approval: Domestic Politics and Multilateral Authorization for War. Chicago, IL: University of Chicago Press.

Claude, Inis L., 1966, Collective legitimation as a political function of the UN, International Organization 20, 3: 367-79.

Copelovitch, Mark, 2010, Master or Servant? Agency Slack and the Politics of IMF Lending, International Studies Quarterly 54, 1: 49-77.

Dixit, Avinash and John Londregan, 1996, The determinants of success of special interests in redistributive politics. Journal of Politics 58 (4): 1132-55.

Doyle, Michael W., 2001, The New Interventionism, Metaphilosophy 32: 212-235.

Dreher, Axel. 2006. IMF and Economic Growth: The Effects of Programs, Loans, and Compliance with Conditionality, World Development 34, 5: 769-788.

Dreher, Axel and Nathan M. Jensen. 2007. Independent Actor or Agent? An Empirical Analysis of the Impact of US Interests on IMF Conditions, Journal of Law and Economics 50, 1: 105124.

Dreher, Axel and Jan-Egbert Sturm. 2010. Do the IMF and the World Bank Influence Voting in the UN General Assembly? Public Choice, forthcoming. 
Dreher, Axel, Jan-Egbert Sturm, and James Raymond Vreeland. 2009a. Global Horse Trading: IMF Loans for Votes in the United Nations Security Council? European Economic Review 53 (7): $742-757$.

Dreher, Axel, Jan-Egbert Sturm, and James Raymond Vreeland. 2009b. Development Aid and International Politics: Does Membership on the UN Security Council Influence World Bank Decisions? Journal of Development Economics 88 (1): 1-18.

Dreher, Axel, Jan-Egbert Sturm, and James Raymond Vreeland. 2010. Does membership on the UN Security Council influence IMF conditionality? Center for European, Governance and Economic Development Research Working Paper No. 104.

Eldar, Ofer, 2008. Vote-Trading in International Institutions, European Journal of International Law 19, 1: 3-41.

Faini, Riccardo and Enzo Grilli. 2004. Who Runs the IFIs? CEPR Discussion Paper No. 4666.

Fang, Songying, 2008, The informational role of international institutions and domestic politics, American Journal of Political Science 52, 2: 304-321.

Fischer, Stanley. 1999. On the Need for an International Lender of Last Resort. Prepared for delivery at the joint luncheon of the American Economic Association and the American Finance Association, New York, January 3 1999. Available at www.imf.org.

Fratianni, Michele and John Pattison, 2005, Who is Running the IMF: Critical Shareholders or the Staff? In: P. de Gijsel and H. Schenk (eds), Multidisciplinary Economics: The Birth of a New Economics Faculty in the Netherlands, Berlin: Springer, 279-292.

Harrigan, Jane; Chengang Wang and Hamed El-Said. 2006. The Economic and Political Determinants of IMF and World Bank Lending in the Middle East and North Africa, World Development 34, 2: 247-270. 
Hurd, Ian, 2007, After Anarchy: Legitimacy and Power in the UN Security Council, Princeton: Princeton University Press.

Hurd, Ian and Bruce Cronin (eds.), 2008, The UN Security Council and the Legitimacy of International Authority, New York: Routledge.

Kegley, Charles W. Jr. and Steven W. Hook. 1991. U.S. Foreign Aid and U.N. Voting: Did Reagan's Linkage Strategy Buy Defence or Defiance? International Studies Quarterly $35,3: 295-312$.

Kilby, Christopher. 2011. Informal influence in the Asian Development Bank, Review of International Organizations, forthcoming.

Kilby, Christopher. 2009. The Political Economy of Conditionality: an Empirical Analysis of World Bank Loan Disbursements, Journal of Development Economics 89, 1: 51-61.

Kuziemko, Ilyana and Eric Werker. 2006. How Much Is a Seat on the Security Council Worth? Foreign Aid and Bribery at the United Nations. Journal of Political Economy 114 (5): 905-930.

Lim, Daniel and James Raymond Vreeland. 2011. Regional Organizations and International Politics: The Asian Development Bank and the United Nations Security Council. Paper prepared for the 4th Annual Conference on the Political Economy of International Organizations.

Malone, David M., 1998, Decision-Making in the UN Security Council: The Case of Haiti, 1990-1997, New York: Oxford University Press.

McKeown, Timothy, 2009, How U.S. decision-makers assessed their control of multilateral organizations, 1957-1982, Review of International Organizations 4, 3: 269-291. 
Moser, Christoph and Jan-Egbert Sturm. 2011. Explaining IMF Lending Decisions after the Cold War, Review of International Organizations 6, 2-3, forthcoming.

Oatley, Thomas and Jason Yackee. 2004. American Interests and IMF Lending, International Politics 41, 3: 415-429.

O'Neill, Barry, 1996, Power and Satisfaction in the United Nations Security Council, Journal of Conflict Resolution 40, 2: 219-237.

Rieffel, Lex. 2003. Restructuring Sovereign Debt: The Case for ad-hoc Machinery, Brookings Institution Press, Washington, D.C.

Sandler, Todd and Keith Hartley, 1999, The Political Economy of NATO: Past, Present, and into the 21st Century, Cambridge: Cambridge University Press.

Sexton, Edwin A. and Terence N. Decker. 1992. U.S. Foreign Aid: Is It for Friends, Development or Politics, The Journal of Social, Political and Economic Studies 17, 3 \& 4: 303-315.

Stein, Howard, 1992, Economic Policy and the IMF in Tanzania: Conditionality, Conflict, and Convergence, in: Horace Campbell and Howard Stein (eds.), Tanzania and the IMF: The Dynamics of Liberalization, Boulder: Westview Press: 59-83.

Steinwand Martin C. and Randall W. Stone. 2008. The International Monetary Fund: A review of the recent evidence, Review of International Organizations 3, 2: 123-149.

Stone, Randall W. 2002. Lending Credibility, Princeton, NJ: Princeton University Press.

Stone, Randall W. 2004, The Political Economy of IMF Lending in Africa, American Political Science Review 98, 4: 577-592.

Stone, Randall, 2008, The Scope of IMF Conditionality, International Organization 62: 589-620. 
Stone, Randall W. 2011. Controlling Institutions: International Organizations and the Global Economy. New York: Cambridge University Press.

Sturm, Jan-Egbert, Helge Berger and Jakob de Haan, 2005, Which Variables Explain Decisions on IMF Credit? An Extreme Bounds Analysis, Economics \& Politics 17, 2: 177-213.

Thacker, Strom C., 1999, The High Politics of IMF Lending, World Politics 52: 38-75.

Thompson, Alexander, 2006a, Coercion through IOs: The Security Council and the logic of information transmission, International Organization 60, 1: 1-34.

Thompson, Samuel B., 2006b. Simple Formulas for Standard Errors that Cluster by Both Firm and Time. Mimeo. Harvard University.

Vaubel, Roland. 1986. A Public Choice Approach to International Organization. Public Choice 51: 39-57.

Voeten, Erik, 2001, Outside Options and the Logic of Security Council Action, American Political Science Review, 95, 4: 845-858.

Voeten, Erik, 2005, The Political Origins of the UN Security Council's Ability to Legitimize the Use of Force, International Organization, 59, 3: 527-557.

Vreeland, James Raymond. 2003. The IMF and Economic Development. New York: Cambridge University Press.

Vreeland, James Raymond. 2007. The International Monetary Fund: Politics of Conditional Lending. New York: Routledge.

Wittkopf, Eugene. 1973. Foreign Aid and United Nations Votes: A Comparative Study, American Political Science Review 67, 3: 868-888. 
Woods, Ngaire, 2003, The United States and the International Financial Institutions: Power and Influence within the World Bank and the IMF, in: Foot, McFarlane and Mastanduno (Eds.), US Hegemony and International Organizations, Oxford: 92-114. 
Figure 1: UNSC voting and IMF participation - all programs

\section{all IMF programs}

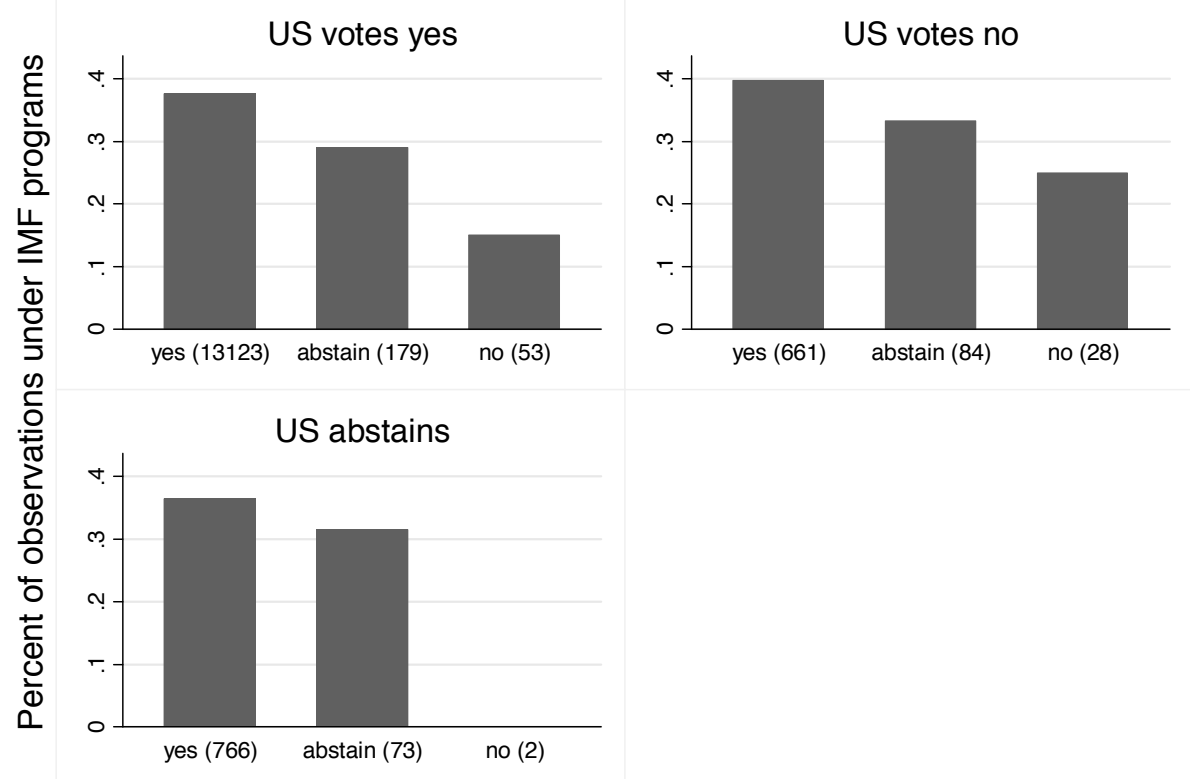

Note: Numbers in parentheses give total number of observations in each category.

Figure 2: UNSC voting and IMF participation - concessional programs concessional IMF programs

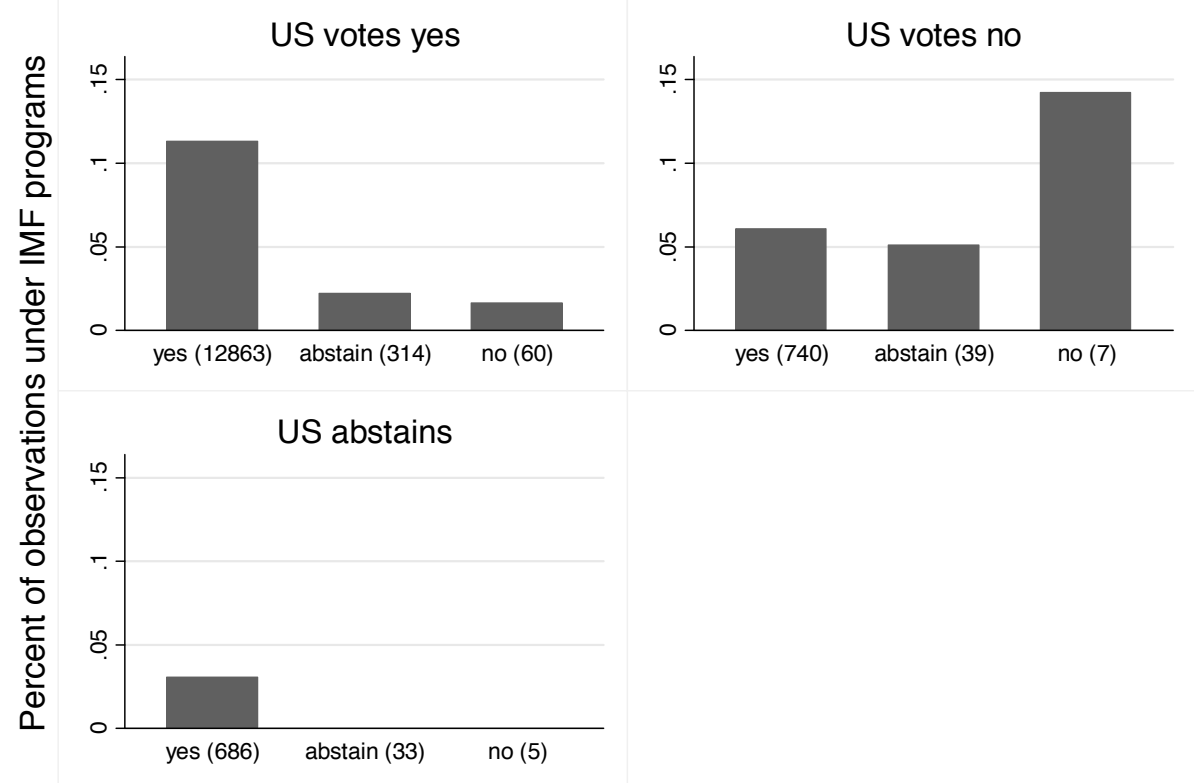

Note: Numbers in parentheses give total number of observations in each category. 
Figure 3: UNSC voting and IMF loans (commitments in mill. SDR) - all programs

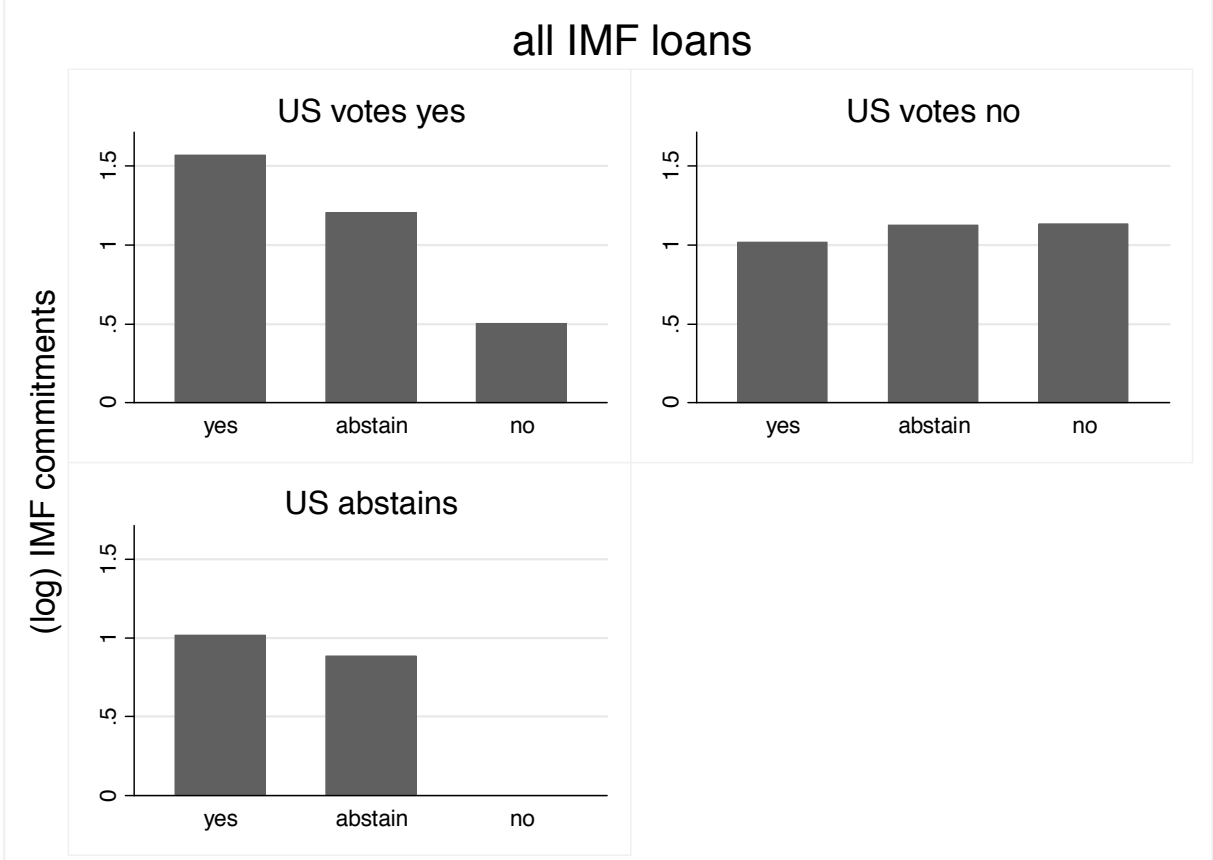

Figure 4: UNSC voting and IMF loans (commitments in mill. SDR) - concessional programs

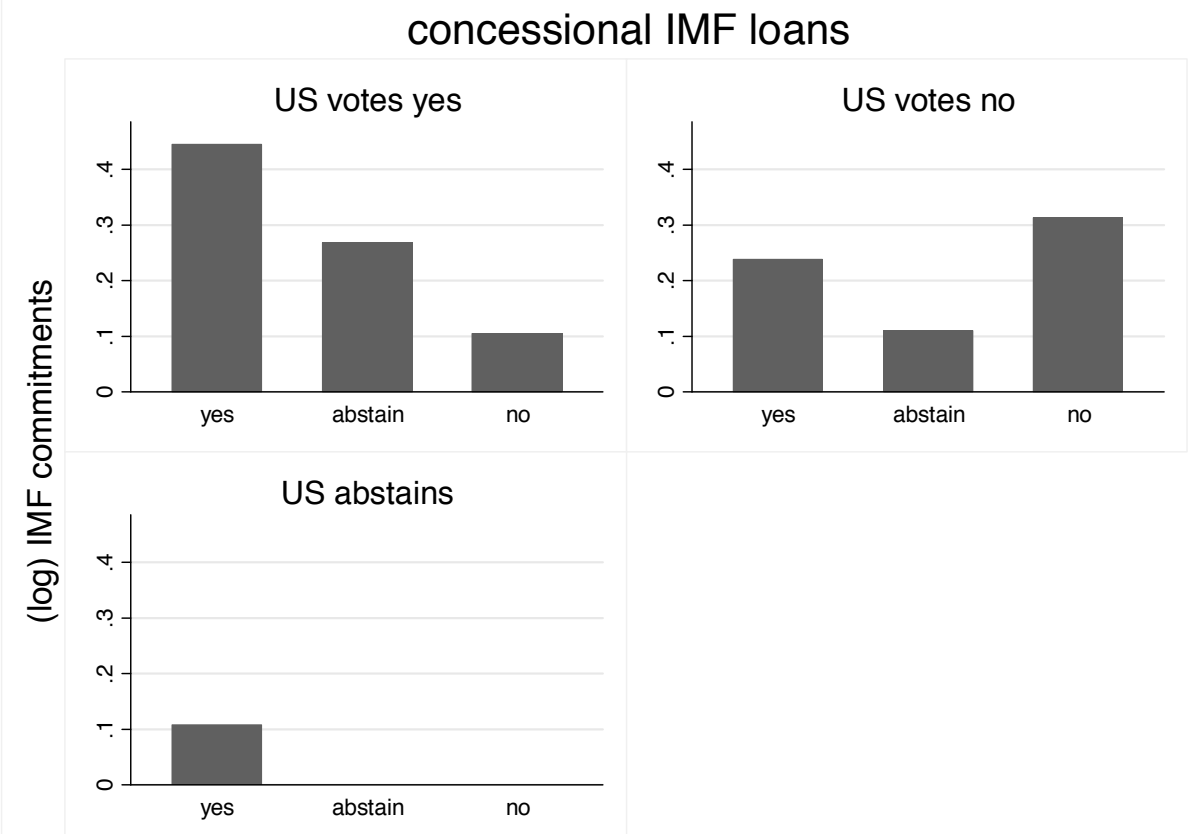


Figure 5: Partial Leverage Plot, Table 1, column 8

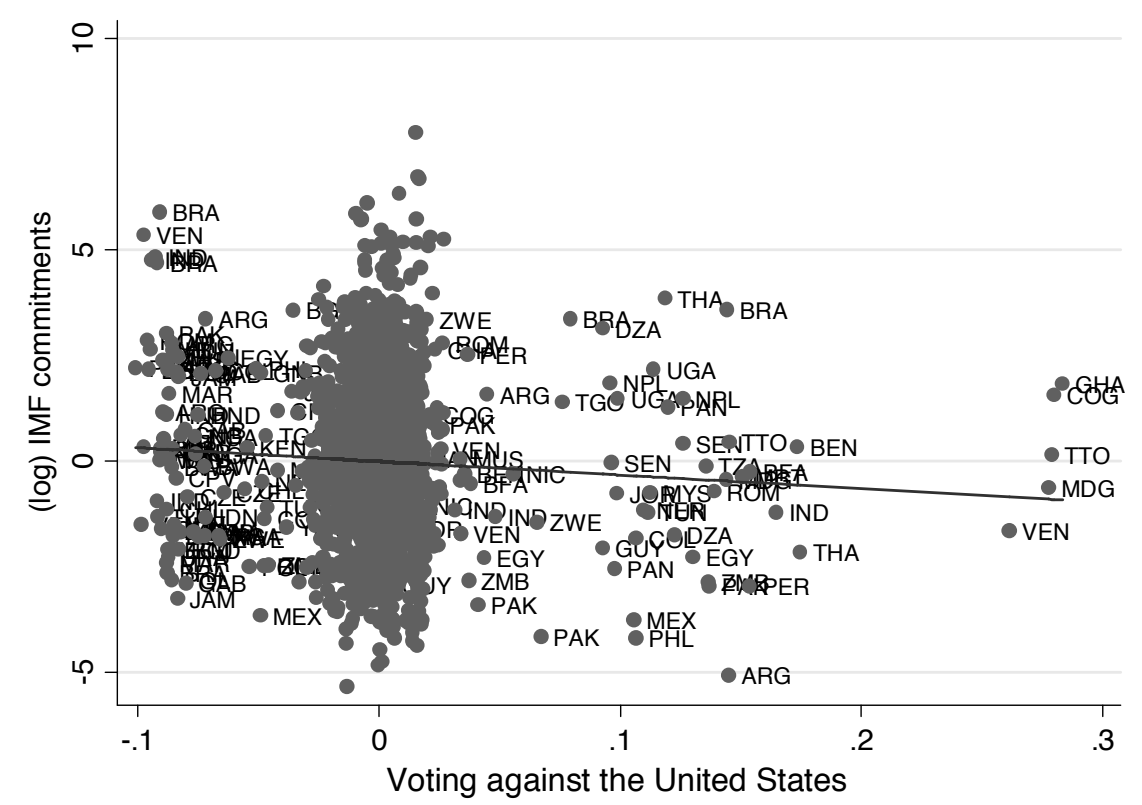

Figure 6: Marginal effect, Table 3, column 2

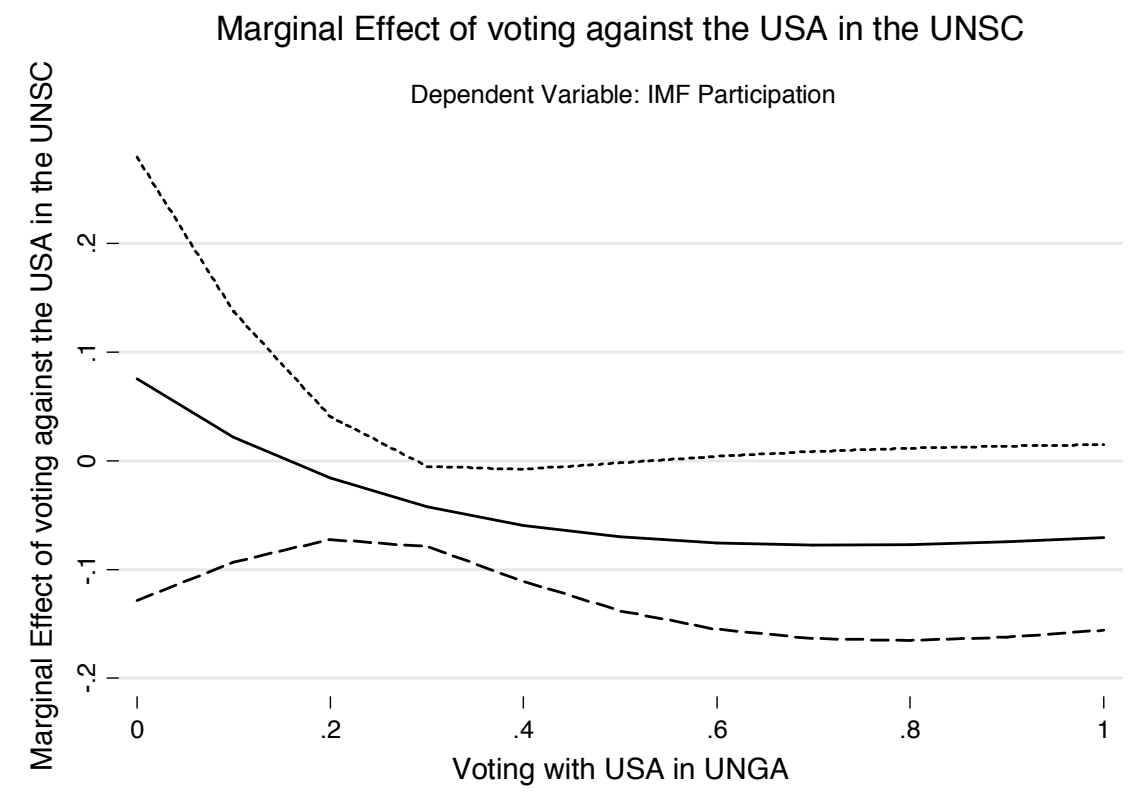


Figure 7: Marginal effect, Table 3, column 4

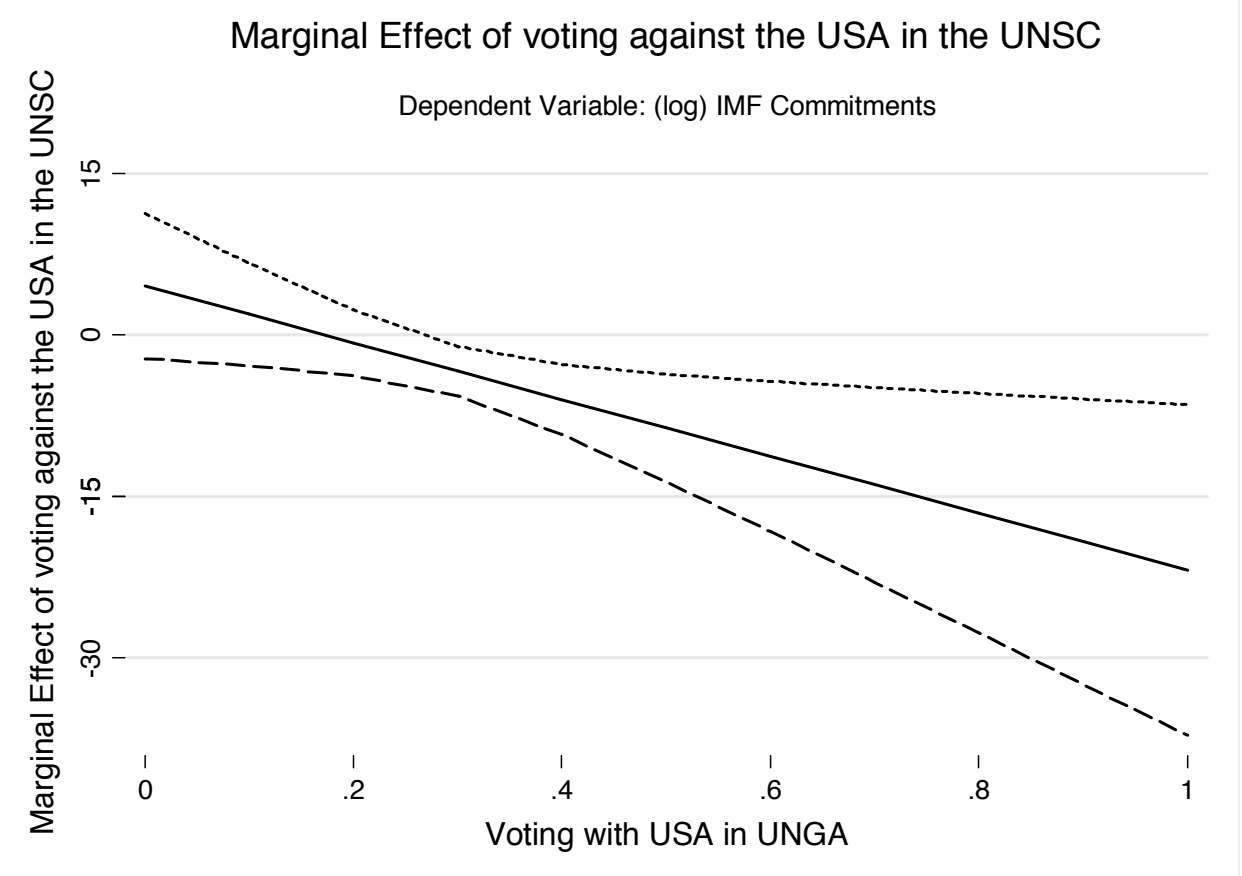


Table 1: UNSC voting and the IMF, 1970-2000

\begin{tabular}{|c|c|c|c|c|c|c|c|c|}
\hline & $\begin{array}{c}\text { (1) } \\
\text { programs }\end{array}$ & $\begin{array}{c}\text { (2) } \\
\text { programs }\end{array}$ & $\begin{array}{c}\text { (3) } \\
\text { programs }\end{array}$ & $\begin{array}{c}\text { (4) } \\
\text { committm. }\end{array}$ & $\begin{array}{c}\text { (5) } \\
\text { committm. }\end{array}$ & $\begin{array}{c}(6) \\
\text { committm. }\end{array}$ & $\begin{array}{c}(7) \\
\text { committm. }\end{array}$ & $\begin{array}{c}\text { (8) } \\
\text { committm. }\end{array}$ \\
\hline UNSC temporary membership & $\begin{array}{l}0.595^{* * *} \\
(0.00)\end{array}$ & $\begin{array}{l}-0.964 \\
(0.25)\end{array}$ & $\begin{array}{l}0.907^{* * *} \\
(0.00)\end{array}$ & $\begin{array}{r}0.089 \\
(0.70)\end{array}$ & $\begin{array}{l}-1.709^{*} \\
(0.07)\end{array}$ & $\begin{array}{r}0.435 \\
(0.18)\end{array}$ & $\begin{array}{l}-1.935^{* *} \\
(0.03)\end{array}$ & $\begin{array}{c}0.391^{*} \\
(0.07)\end{array}$ \\
\hline Voting with USA & & $\begin{array}{l}1.821^{*} \\
(0.06)\end{array}$ & & & $\begin{array}{l}2.086^{*} \\
(0.05)\end{array}$ & & $\begin{array}{l}2.303^{* *} \\
(0.02)\end{array}$ & \\
\hline Voting against USA & & & $\begin{array}{l}-2.952^{* *} \\
(0.04)\end{array}$ & & & $\begin{array}{l}-3.290 \\
(0.16)\end{array}$ & & $\begin{array}{l}-3.226^{* *} \\
(0.02)\end{array}$ \\
\hline Past participation & $\begin{array}{l}2.259^{* * *} \\
(0.00)\end{array}$ & $\begin{array}{l}2.247^{* * *} \\
(0.00)\end{array}$ & $\begin{array}{l}2.259 * * * \\
(0.00)\end{array}$ & $\begin{array}{r}0.546 \\
(0.11)\end{array}$ & $\begin{array}{c}0.532 \\
(0.11)\end{array}$ & $\begin{array}{l}0.554 \\
(0.10)\end{array}$ & $\begin{array}{l}0.592^{* * *} \\
(0.01)\end{array}$ & $\begin{array}{l}0.608^{* * *} \\
(0.00)\end{array}$ \\
\hline $\log ($ real GDP per capita) & $\begin{array}{l}-2.107^{* * *} \\
(0.00)\end{array}$ & $\begin{array}{l}-2.112^{* * *} \\
(0.00)\end{array}$ & $\begin{array}{l}-2.140^{* * *} \\
(0.00)\end{array}$ & $\begin{array}{l}-1.695^{* *} \\
(0.01)\end{array}$ & $\begin{array}{l}-1.687^{* *} \\
(0.01)\end{array}$ & $\begin{array}{l}-1.707^{* *} \\
(0.01)\end{array}$ & $\begin{array}{l}-1.416^{* * *} \\
(0.00)\end{array}$ & $\begin{array}{l}-1.426^{* * *} \\
(0.00)\end{array}$ \\
\hline Investment (in percent of GDP) & $\begin{array}{l}-0.082^{* * *} \\
(0.00)\end{array}$ & $\begin{array}{l}-0.082^{* * *} \\
(0.00)\end{array}$ & $\begin{array}{l}-0.081^{* * *} \\
(0.00)\end{array}$ & $\begin{array}{l}-0.060^{* * *} \\
(0.01)\end{array}$ & $\begin{array}{l}-0.060^{* * *} \\
(0.01)\end{array}$ & $\begin{array}{l}-0.060^{* * *} \\
(0.01)\end{array}$ & $\begin{array}{l}-0.043^{* * *} \\
(0.00)\end{array}$ & $\begin{array}{l}-0.043^{* * *} \\
(0.00)\end{array}$ \\
\hline Debt service (in percent of GDP) & $\begin{array}{l}0.027^{* * *} \\
(0.00)\end{array}$ & $\begin{array}{l}0.027^{* * *} \\
(0.00)\end{array}$ & $\begin{array}{l}0.028^{* * *} \\
(0.00)\end{array}$ & $\begin{array}{l}0.019^{* *} \\
(0.01)\end{array}$ & $\begin{array}{l}0.020^{* *} \\
(0.01)\end{array}$ & $\begin{array}{l}0.020^{* *} \\
(0.01)\end{array}$ & $\begin{array}{l}0.021^{* * *} \\
(0.00)\end{array}$ & $\begin{array}{l}0.021^{* * *} \\
(0.00)\end{array}$ \\
\hline (log) Number of checks and balances & $\begin{array}{l}0.253^{* * *} \\
(0.00)\end{array}$ & $\begin{array}{l}0.243^{* * *} \\
(0.00)\end{array}$ & $\begin{array}{l}0.246^{* * *} \\
(0.00)\end{array}$ & $\begin{array}{l}0.027 \\
(0.89)\end{array}$ & $\begin{array}{l}0.024 \\
(0.91)\end{array}$ & $\begin{array}{l}0.031 \\
(0.88)\end{array}$ & & \\
\hline Overall budget balance (\% of GDP) & $\begin{array}{l}0.028^{* *} \\
(0.03)\end{array}$ & $\begin{array}{l}0.028^{* *} \\
(0.04)\end{array}$ & $\begin{array}{l}0.027^{* *} \\
(0.05)\end{array}$ & $\begin{array}{r}0.017 \\
(0.35)\end{array}$ & $\begin{array}{l}0.016 \\
(0.37)\end{array}$ & $\begin{array}{l}0.016 \\
(0.37)\end{array}$ & & \\
\hline Number of observations & 1262 & 1262 & 1262 & 1524 & 1524 & 1524 & 2196 & 2196 \\
\hline Number of countries & 69 & 69 & 69 & 103 & 103 & 103 & 120 & 120 \\
\hline R-Squared & & & & 0.09 & 0.09 & 0.09 & 0.10 & 0.10 \\
\hline
\end{tabular}

Notes: The dependent variable is a dummy indicating the existence of an IMF program in columns (1)-(3) and (log) IMF commitments in millions SDR in columns (4)-(8). Estimation is with two-way clustered conditional fixed effects logit in column (1)-(3) and OLS including fixed country and year effects in columns (4)-(8). p-values in parentheses; *, **, *** significant at $10,5,1 \%$. 
Table 2: UNSC voting and the IMF, including voting with Russia, 1970-2000

\begin{tabular}{|c|c|c|c|c|c|c|}
\hline & $\begin{array}{c}(1) \\
\text { programs }\end{array}$ & $\begin{array}{l}(2) \\
\text { programs }\end{array}$ & $\begin{array}{c}(3) \\
\text { programs }\end{array}$ & $\begin{array}{c}\text { (4) } \\
\text { committm. }\end{array}$ & $\begin{array}{c}\text { (5) } \\
\text { committm. }\end{array}$ & $\begin{array}{c}(6) \\
\text { committm. }\end{array}$ \\
\hline \multirow[t]{2}{*}{ UNSC temporary membership } & -0.231 & $1.034 * * *$ & -1.128 & 0.584 & -1.299 & $0.512 * *$ \\
\hline & $(0.84)$ & $(0.00)$ & $(0.29)$ & $(0.15)$ & $(0.23)$ & $(0.03)$ \\
\hline \multirow[t]{2}{*}{ Voting with USA } & $2.464^{*}$ & & 2.681 & & $2.788^{*}$ & \\
\hline & $(0.06)$ & & $(0.17)$ & & $(0.08)$ & \\
\hline \multirow[t]{2}{*}{ Voting with Russia } & -1.356 & & -1.154 & & -1.110 & \\
\hline & $(0.39)$ & & $(0.59)$ & & $(0.53)$ & \\
\hline \multirow[t]{2}{*}{ Voting against USA } & & $-3.137^{* *}$ & & -3.625 & & $-3.510^{* *}$ \\
\hline & & $(0.04)$ & & $(0.13)$ & & $(0.01)$ \\
\hline \multirow[t]{2}{*}{ Voting against Russia } & & -5.560 & & -5.815 & & -5.390 \\
\hline & & $(0.31)$ & & $(0.42)$ & & $(0.21)$ \\
\hline \multirow[t]{2}{*}{ Past participation } & $2.248 * * *$ & $2.266 * * *$ & 0.536 & $0.570^{*}$ & $0.596 * * *$ & $0.614 * * *$ \\
\hline & $(0.00)$ & $(0.00)$ & $(0.11)$ & $(0.09)$ & $(0.01)$ & $(0.00)$ \\
\hline \multirow[t]{2}{*}{ log(real GDP per capita) } & $-2.120 * * *$ & $-2.162 * * *$ & $-1.694 * *$ & $-1.705^{* *}$ & $-1.421 * * *$ & $-1.420 * * *$ \\
\hline & $(0.00)$ & $(0.00)$ & $(0.01)$ & $(0.01)$ & $(0.00)$ & $(0.00)$ \\
\hline \multirow[t]{2}{*}{ Investment (in percent of GDP) } & $-0.082 * * *$ & $-0.081 * * *$ & $-0.060 * * *$ & $-0.060 * * *$ & $-0.043 * * *$ & $-0.043 * * *$ \\
\hline & $(0.00)$ & $(0.00)$ & $(0.01)$ & $(0.01)$ & $(0.00)$ & $(0.00)$ \\
\hline \multirow[t]{2}{*}{ Debt service (in percent of GDP) } & $0.028 * * *$ & $0.028 * * *$ & $0.020 * *$ & $0.019 * *$ & $0.021 * * *$ & $0.021 * * *$ \\
\hline & $(0.00)$ & $(0.00)$ & $(0.01)$ & $(0.01)$ & $(0.00)$ & $(0.00)$ \\
\hline \multirow[t]{2}{*}{ (log) Number of checks and balances } & $0.244 * * *$ & $0.240 * * *$ & 0.027 & 0.030 & & \\
\hline & $(0.00)$ & $(0.00)$ & $(0.90)$ & $(0.88)$ & & \\
\hline \multirow[t]{2}{*}{ Overall budget balance (\% of GDP) } & $0.027^{* *}$ & $0.027^{* *}$ & 0.016 & 0.016 & & \\
\hline & $(0.05)$ & $(0.05)$ & $(0.37)$ & $(0.37)$ & & \\
\hline Number of observations & 1262 & 1262 & 1524 & 1524 & 2196 & 2196 \\
\hline Number of countries & 69 & 69 & 103 & 103 & 120 & 120 \\
\hline R-Squared & & & 0.09 & 0.09 & 0.10 & 0.10 \\
\hline
\end{tabular}

Notes: The dependent variable is a dummy indicating the existence of an IMF program in columns (1)-(3) and (log) IMF commitments in millions SDR in columns (4)-(6). Estimation is with two-way clustered conditional fixed effects logit in column (1)-(3) and OLS including fixed country and year effects in columns (4)-(8). p-values in parentheses; *,**,*** significant at $10,5,1 \%$. 
Table 3: UNSC voting and UNGA voting, 1970-2000

\begin{tabular}{lllll}
\hline & $(1)$ & $(2)$ & $(3)$ & $(4)$ \\
& programs & programs & $\begin{array}{c}(3) \\
\text { committm. }\end{array}$ & committm. \\
\hline UNSC temporary membership & $1.033^{* * *}$ & $1.103^{* * *}$ & $0.417^{*}$ & $0.468^{* *}$ \\
& $(3.68)$ & $(3.81)$ & $(1.91)$ & $(2.13)$ \\
Voting against USA & $-3.828^{* * *}$ & 4.653 & $-3.221^{* *}$ & 4.530 \\
& $(2.61)$ & $(1.29)$ & $(2.30)$ & $(1.11)$ \\
Voting with USA (UNGA), t-1 & -1.561 & -1.480 & $2.155^{* *}$ & $2.165^{* *}$ \\
& $(1.49)$ & $(1.41)$ & $(2.21)$ & $(2.22)$ \\
Voting against USA (UNSC) & & $-30.225^{* *}$ & & $-26.379^{* *}$ \\
* Voting with USA (UNGA), t-1 & & $(2.43)$ & & $(2.02)$ \\
Debt service (in percent of GDP) & $0.025^{* * *}$ & $0.025^{* * *}$ & $0.021^{* * *}$ & $0.021^{* * *}$ \\
& $(4.13)$ & $(4.09)$ & $(4.89)$ & $(4.82)$ \\
Investment (in percent of GDP) & $-0.078^{* * *}$ & $-0.078^{* * *}$ & $-0.041^{* * *}$ & $-0.040^{* * *}$ \\
& $(7.95)$ & $(7.87)$ & $(4.55)$ & $(4.47)$ \\
Past participation & $2.257^{* * *}$ & $2.254^{* * *}$ & $0.616^{* * *}$ & $0.619^{* * *}$ \\
& $(7.50)$ & $(7.50)$ & $(3.41)$ & $(3.43)$ \\
log(real GDP per capita) & $-2.342^{* * *}$ & $-2.353^{* * *}$ & $-1.337^{* * *}$ & $-1.341^{* * *}$ \\
& $(25.26)$ & $(25.47)$ & $(4.95)$ & $(4.97)$ \\
(log) Number of checks and balances & $0.224^{* * *}$ & $0.220^{* * *}$ & & \\
& $(3.10)$ & $(3.00)$ & & \\
Overall budget balance (\% of GDP) & 0.023 & 0.022 & & \\
& $(1.56)$ & $(1.54)$ & & 2179 \\
\hline Number of observations & 1251 & 1251 & 2179 & 120 \\
Number of countries & 69 & 69 & 120 & 0.11 \\
R-Squared & & & 0.10 & \\
\hline
\end{tabular}

Notes: The dependent variable is a dummy indicating the existence of an IMF program in columns (1)-(2) and (log) IMF commitments in millions SDR in columns (3)-(4). Estimation is with two-way clustered conditional fixed effects logit in column (1)-(2) and OLS including fixed country and year effects in columns (3)-(4). p-values in parentheses; *,**,*** significant at $10,5,1 \%$. 
Appendix A: Variables and Definitions

\begin{tabular}{|c|c|c|}
\hline Variable & Description & Source \\
\hline IMF participation & $\begin{array}{l}\text { Dummy coded } 1 \text { if a country participates in an } \\
\text { IMF program during part of the year under } \\
\text { Stand-by, Extended Fund Facility, Structural } \\
\text { Adjustment Facility, or Extended Structural } \\
\text { Adjustment Facility/Poverty Reduction and } \\
\text { Growth Facility, and } 0 \text { otherwise. }\end{array}$ & Vreeland (2003) \\
\hline $\begin{array}{l}\text { IMF participation, } \\
\text { concessional }\end{array}$ & $\begin{array}{l}\text { Dummy coded } 1 \text { if a country participates in an } \\
\text { IMF program during at least } 5 \text { months of the } \\
\text { year under Structural Adjustment Facility or } \\
\text { Extended Structural Adjustment } \\
\text { Facility/Poverty Reduction and Growth Facility, }\end{array}$ & Dreher (2006) \\
\hline IMF committments & $\begin{array}{l}\text { (log) loans agreed under Stand-by, Extended } \\
\text { Fund Facility, Structural Adjustment Facility, or } \\
\text { Extended Structural Adjustment } \\
\text { Facility/Poverty Reduction and Growth Facility } \\
\text { (in millions SDR). }\end{array}$ & IMF (2005) \\
\hline $\begin{array}{l}\text { IMF committments, } \\
\text { concessional }\end{array}$ & $\begin{array}{l}\text { (log) loans agreed under Structural Adjustment } \\
\text { Facility and Extended Structural Adjustment } \\
\text { Facility/Poverty Reduction and Growth Facility } \\
\text { (in millions SDR). }\end{array}$ & IMF (2005) \\
\hline $\begin{array}{l}\text { UNSC temporary } \\
\text { membership }\end{array}$ & $\begin{array}{l}\text { Dummy coded } 1 \text { if a country is a non-permanent } \\
\text { member of the United Nations Security Council, } \\
\text { and } 0 \text { otherwise. }\end{array}$ & www.un.org \\
\hline $\begin{array}{l}\text { Voting with USA/Russia in } \\
\text { the UNSC }\end{array}$ & $\begin{array}{l}\text { Share of votes a country votes in line with the } \\
\text { United States/Russia in the UNSC. }\end{array}$ & see text \\
\hline $\begin{array}{l}\text { Voting against USA/Russia } \\
\text { in the UNSC }\end{array}$ & $\begin{array}{l}\text { Share of votes a country votes against the } \\
\text { United States/Russia in the UNSC. }\end{array}$ & see text \\
\hline $\begin{array}{l}\text { Voting with USA in the } \\
\text { UNGA }\end{array}$ & $\begin{array}{l}\text { Share of votes a country votes with the United } \\
\text { States in the UNGA. }\end{array}$ & see text \\
\hline Past Participation & $\begin{array}{l}\text { Dummy coded } 1 \text { for countries that have } \\
\text { previously participated in IMF programs and } 0 \\
\text { otherwise. }\end{array}$ & $\begin{array}{l}\text { IMF Annual Report (various } \\
\text { years) }\end{array}$ \\
\hline log(real GDP per capita) & Measured in 1995 PPP dollars & $\begin{array}{l}\text { Przeworski et al. (2000), } \\
\text { extended by Cheibub et al. }\end{array}$ \\
\hline $\begin{array}{l}\text { Investment (in percent of } \\
\text { GDP) }\end{array}$ & $\begin{array}{l}\text { Private and public gross national investment as } \\
\text { a share of gross domestic product (GDP). }\end{array}$ & $\begin{array}{l}\text { Przeworski et al. (2000), } \\
\text { extended by Cheibub et al. }\end{array}$ \\
\hline $\begin{array}{l}\text { Debt service (in percent of } \\
\text { GDP) }\end{array}$ & $\begin{array}{l}\text { Total debt service outstanding in percent of } \\
\text { GNI. }\end{array}$ & World Bank (2004) \\
\hline $\begin{array}{l}\text { (log) Number of checks and } \\
\text { balances }\end{array}$ & Log of the number of checks and balances. & Beck et al. (1999) \\
\hline $\begin{array}{l}\text { Overall budget balance ( } \% \\
\text { of GDP) }\end{array}$ & $\begin{array}{l}\text { Overall budget balance is current and capital } \\
\text { revenue and official grants received, less total } \\
\text { expenditure and lending minus repayments for } \\
\text { central government in percent of GDP. }\end{array}$ & World Bank (2004) \\
\hline
\end{tabular}


Appendix B: Descriptive Statistics (estimation sample, Table 1, column 7)

\begin{tabular}{|l|}
\hline Variable \\
\hline IMF participation \\
IMF participation, concessional \\
IMF committments \\
IMF committments, concessional \\
UNSC temporary membership \\
Voting with USA in the UNSC \\
Voting with Russia in the UNSC \\
Voting against USA in the UNSC \\
Voting against Russia in the UNSC \\
Voting with USA in the UNGA \\
Past Participation \\
log(real GDP per capita) \\
Investment (in percent of GDP) \\
Debt service (in percent of GDP) \\
(log) Number of checks and \\
Overall budget balance (\% of GDP)
\end{tabular}

\begin{tabular}{|c|}
\hline Mean \\
\hline 0.50 \\
0.16 \\
1.60 \\
0.50 \\
0.07 \\
0.06 \\
0.07 \\
0.01 \\
0.00 \\
0.37 \\
0.79 \\
7.91 \\
12.93 \\
18.59 \\
0.62 \\
-3.33 \\
\hline
\end{tabular}

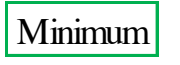

Maximum

Standard Deviation

\begin{tabular}{|c|}
\hline 0.00 \\
0.00 \\
0.00 \\
0.00 \\
0.00 \\
0.00 \\
0.00 \\
0.00 \\
0.00 \\
0.00 \\
0.00 \\
6.05 \\
-3.46 \\
0.00 \\
0.00 \\
-61.14 \\
\hline
\end{tabular}

\begin{tabular}{|c|}
\hline 1.00 \\
1.00 \\
9.67 \\
7.96 \\
1.00 \\
1.00 \\
1.00 \\
0.42 \\
0.13 \\
0.69 \\
1.00 \\
9.72 \\
68.35 \\
152.27 \\
2.89 \\
20.63 \\
\hline
\end{tabular}

